\title{
Pathways and receptors involved in peptide YY induced contraction of rat proximal colonic muscle in vitro
}

\author{
L Ferrier, J-P Segain, P Pacaud, C Cherbut, G Loirand, J-P Galmiche, H M Blottière
}

\begin{abstract}
Background-Peptide YY (PYY) is involved in the regulation of several gut functions, including secretion and motility. It exerts its effects through a family of six receptors, commonly named the $Y$ receptor family.

Aims-To characterise the effects of PYY on strips of rat proximal colon in vitro, and to determine the pathways and receptors involved.

Methods-Contractions of strips removed from the muscle layer of rat proximal colon were recorded under isometric conditions, using PYY, Y receptor agonists and antagonists, and nerve blockers. Reverse transcription-polymerase chain reaction was also performed to detect the presence of $\mathrm{mRNA}$ coding for $\mathrm{Y}$ receptors. Finally, smooth muscle cells were isolated to estimate the cell length and intracellular $\mathrm{Ca}^{2+}$ concentration in the presence and absence of PYY.

Results-PYY, neuropeptide Y (NPY), pancreatic polypeptide (PP) and [Leu31,Pro34]NPY induced a dose dependent contraction of strips from proximal colon. Tetrodotoxin partially inhibited the PYY and NPY induced contractions, and strongly inhibited the $P P$ induced contraction. Specific antagonists showed the involvement of cholinergic nicotinic receptors and NK1 receptor. BIBP 3226, a specific Y1 antagonist, did not modify the colonic smooth muscle response to PYY, whereas blocking L-type $\mathrm{Ca}^{2+}$ channels with $\mathrm{D}-600$ abolished its effects. Moreover, PYY induced an increase in intracellular $\mathrm{Ca}^{2+}$ concentration, associated with a reduction in cell length. mRNA encoding $Y 1$ and $Y 4$ receptors were detected in the muscle strips.

Conclusions-These findings suggest that PYY stimulates colonic contractile activity in vitro through (a) a nervous Y4 dependent pathway and (b) a pathway involving a potential new receptor on myocytes. (Gut 2000;46:370-375)
\end{abstract}

Keywords: peptide YY; Y receptors; colon; motility; myocytes

Peptide YY (PYY) is a 36 amino acid gastrointestinal peptide discovered in 1982 by Tatemoto and co-workers. ${ }^{1}$ It is produced by enteroendocrine $\mathrm{L}$ cells of the hindgut mucosa ${ }^{2}$ and is also found in the enteric nerv- ous system. ${ }^{3}$ It is a member of the PP fold peptide family, which includes neuropeptide Y (NPY), a neuropeptide widely present in central and peripheral nervous systems, and pancreatic polypeptide (PP). ${ }^{4}$ PYY release is stimulated by several factors, including the presence of nutrients in the duodenum or in the distal part of the gut. ${ }^{5}$ Potent PYY releasers are amino acids ${ }^{6}$ and short chain fatty acids ${ }^{7-9}$ present in the large intestine.

PYY displays several physiological functions throughout the gut including secretory and motor activities. Centrally injected into rats, this peptide inhibits gastric emptying through a cholinergic nervous pathway in vivo, ${ }^{10}$ and stimulates phasic activity of rat duodenum in vivo. ${ }^{11}$ In the isolated perfused canine ileum, it stimulates phasic contractions through inhibition of nitric oxide release and stimulation of acetylcholine release. ${ }^{12}$ Concerning the colon, PYY and NPY have been shown to inhibit colonic motility in cats in vivo ${ }^{13}$ and in guinea pigs in vitro. ${ }^{14}$ Two distinct mechanisms may exist: NPY may stimulate noradrenaline (norepinephrine) release, which inhibits acetylcholine secretion, whereas PYY directly inhibits acetylcholine secretion by a presynaptic receptor on cholinergic neurones. Wager-Pagé and co workers ${ }^{11}$ showed in rats a stimulatory effect of PYY in vivo, and a recent study by our team showed that PYY is implicated in the short chain fatty acid induced inhibition of myoelectric colonic activity.

PYY and related peptides exert their effects through several receptors (for reviews, see ${ }^{15}$ and ${ }^{16}$ ), together named the Y receptor family. So far, six Y receptors have been identified; five of them have been cloned and four (Y1, Y2, Y5, and Y6) are able to bind PYY with high affinity. The Y3 receptor has been pharmacologically described as being specific for NPY, but has not yet been cloned. The Y4 receptor, also called PP1 receptor, binds PP with high affinity, whereas it has a weaker affinity for PYY and NPY. In mice, the Y6 receptor has recently been cloned but the agonist potency remains unclear. In humans, such a receptor has also been found, but in a truncated non-functional form. However, in rats, this receptor has not been found in any tissue. ${ }^{17}$ In addition, a PYY preferring receptor has also been described in

Abbreviations used in this paper: PYY, peptide YY; NPY, neuropeptide Y; PP, pancreatic polypeptide; RT-PCR, reverse transcription-polymerase chain reaction; $\mathrm{ACh}$, acetylcholine chloride; $5 \mathrm{HT}$, 5-hydroxytryptamine; $\left[\mathrm{Ca}^{2+}\right]_{\mathrm{i}}$, intracellular $\mathrm{Ca}^{2+}$ concentration. 
Table 1 Relative potency of agonists and antagonists to $Y$ receptors ${ }^{15} 16$

\begin{tabular}{lll}
\hline Receptor & Agonists & Antagonist \\
\hline $\mathrm{Y} 1$ & $\mathrm{PYY} \geqslant \mathrm{NPY} \geqslant\left[\mathrm{Leu}^{31}, \mathrm{Pro}^{34}\right] \mathrm{NPY}>>\mathrm{PP}$ & BIBP 3226 \\
$\mathrm{Y} 2$ & $\mathrm{NPY}=\mathrm{PYY} \geqslant \mathrm{NPY}(13-36)>>\mathrm{PP}$ & \\
$\mathrm{Y} 3$ & $\mathrm{NPY}>>\mathrm{PYY}=\mathrm{PP}$ & \\
$\mathrm{Y} 4$ & $\mathrm{PP}>\left[\mathrm{Leu}^{31}, \mathrm{Pro}^{34}\right] \mathrm{NPY}>\mathrm{PYY}=\mathrm{NPY}$ & \\
$\mathrm{Y} 5$ & $\mathrm{NPY}=\mathrm{PYY}=\left[\mathrm{Leu}^{31}, \mathrm{Pro}^{34}\right] \mathrm{NPY} \geqslant \mathrm{NPY}(13-36)$ & \\
\hline
\end{tabular}

PYY, peptide YY; NPY, neuropeptide Y; PP, pancreatic polypeptide.

the epithelium of the rat small intestine, but has not yet been cloned. ${ }^{18}$ All the cloned receptors belong to the $\mathrm{G}$ protein coupled receptor family and seem to be linked to $\mathrm{G}_{\mathrm{i}} / \mathrm{G}_{0}$ proteins.

The aims of this study were to characterise the effects of PYY on the motility of rat proximal colon in vitro and to elucidate the pathways and receptors involved.

\section{Materials and methods}

MEASUREMENT OF STRIP CONTRACTIONS

Male Wistar rats were used following the guiding principles in the care and use of animals described in the Declaration of Helsinki. Animals were killed by stunning and cervical dislocation. A median laparotomy was performed, and the external side of the proximal colon was peeled and cut into $1-1.5 \mathrm{~cm}$ long strips of nerve and muscle, referred to as the nerve/muscle preparation, as described elsewhere. ${ }^{19}$ These preparations included both plexuses and muscular layers, and were oriented longitudinally in $37^{\circ} \mathrm{C}$ warmed $5 \mathrm{ml}$ organ baths, containing oxygenated Krebs bicarbonate buffer. Buffer was composed of (mM): $\mathrm{NaCl}$ (128), $\mathrm{KCl}$ (4.5), $\mathrm{CaCl}_{2}$ (2.5), $\mathrm{MgSO}_{4}$ (1.18), $\mathrm{KH}_{2} \mathrm{PO}_{4}$ (1.18), $\mathrm{NaHCO}_{3}(25)$, glucose (11). A tension of $1 \mathrm{~g}$ was applied to the strips, and a one hour equilibration period was allowed. An isometric transducer, linked to the preparation, was used to record strip contractile activity. Before and after each experiment, $\mathrm{KCl} 40 \mathrm{mM}$ and acetylcholine chloride (ACh) $10^{-6} \mathrm{M}$ were added successively to test strip functionality. The resulting contraction was used to express our results as a percentage of a $10^{-6} \mathrm{M}$ ACh induced contraction. Then, strips were rinsed three times with buffer, and a 20 minute recovery period was allowed. PYY was used at increasing concentrations in a cumulative manner $\left(10^{-8}-10^{-5} \mathrm{M}\right)$.

To investigate the receptor involved in the PYY induced contraction of colonic strips, agonists and antagonists for $\mathrm{Y}$ receptors were used (table 1). The specific nerve blocker tetrodotoxin was used to determine the nervous part of the PYY effect. Finally, antagonists for contractile mediator receptors were used to examine the mechanism of action of PYY: atropine, a muscarinic receptor antagonist; hexamethonium, a nicotinic receptor antago- nist; methiotepin, a 5-hydroxytryptamine $(5 \mathrm{HT})_{1 / 2}$ receptor antagonist; SR 140333, an NK1 receptor antagonist; SR 48968, an NK2 receptor antagonist; D-600, a specific L-type $\mathrm{Ca}^{2+}$ channel blocker.

REVERSE TRANSCRIPTION-POLYMERASE CHAIN REACTION (RT-PCR)

RT-PCR was performed on the proximal colon nerve/muscle preparation. Briefly, strips were rinsed in phosphate buffered saline, snap frozen in liquid nitrogen, and homogenised. RNA was isolated from the nerve/muscle preparation using the acid guanidinium isothiocyanate/phenol/chloroform extraction method $^{20}$ and spectrophotometrically quantified. RNA isolated from rat brain was used as a positive control of expression of all Y receptor subtypes. cDNA synthesis was performed with $1 \mu \mathrm{g}$ total RNA using random primers and murine Moloney leukaemia virus reverse transcriptase according to the manufacturer's instructions (Gibco-BRL, Cergy Pontoise, France). PCR was performed using $1 \mu l$ of the reverse transcription reaction mixture, 0.5 unit Gold Star DNA polymerase (Eurogentec, Seraing, Belgium), $3 \mu \mathrm{l} 25 \mathrm{mM} \mathrm{MgCl}, 1 \mu 10$ mM dNTPs, $5 \mu \mathrm{l} 10 \times$ Goldstar DNA polymerase buffer, and $50 \mathrm{pmol}$ of each sense and antisense primer under the following conditions ( 35 cycles): $92^{\circ} \mathrm{C}$ for 40 seconds, $58^{\circ} \mathrm{C}$ for 40 seconds, and $72^{\circ} \mathrm{C}$ for 50 seconds. Primers for Y1, Y2, Y4, and Y5 receptors and for glyceraldehyde-3-phosphate dehydrogenase (Genosys, Pampisford, UK) as housekeeping gene were used (table 2). As the rat Y2 receptor has not yet been cloned, we used primers for the Y2 receptor as described by Goumain and co-workers. ${ }^{21}$ PCR products were separated on $2 \%$ agarose gel and stained with ethidium bromide.

ISOLATION OF COLONIC SMOOTH MUSCLE CELLS Smooth muscle cells were isolated as described previously by Blottière and co-workers. ${ }^{22}$ Briefly, strips from the colon muscle layer were removed and maintained in PSS/Hepes buffer $(\mathrm{NaCl} 130$ $\mathrm{mM}$; KCl $5.6 \mathrm{mM}$, Hepes $8 \mathrm{mM}$, glucose $2 \mathrm{~g} / 1$; $\mathrm{pH}$ 7.4), containing $2 \mathrm{mM} \mathrm{Ca}^{2+} / 1 \mathrm{mM} \mathrm{Mg}^{2+}$. Strips were then cut into small pieces and incubated at $37^{\circ} \mathrm{C}$ for two periods of 30 minutes in a $\mathrm{Ca}^{2+}$-free collagenase solution: phosphate buffered saline $/ 2 \%$ bovine serum albumin $/ 0.1 \%$ collagenase $/ 0.05 \%$ soybean trypsin inhibitor/ $0.01 \%$ Pronase. Then, the tissue was rinsed with collagenase-free buffer. Strip pieces were recovered by centrifugation, and cells were dispersed by gently pipetting into PSS/Hepes $/ 0.8 \mathrm{mM}$ $\mathrm{Ca}^{2+}$. Cell contraction was measured at room temperature, in the presence of PYY or $\mathrm{ACh}$,

Table 2 Primers used for reverse transcription polymerase chain reaction (RT-PCR) experiments

\begin{tabular}{llll}
\hline Primers for & Sense primers & Antisense primers & $\begin{array}{l}\text { Size of PCR products } \\
(b p)\end{array}$ \\
\hline Y1 receptor & AACCTCTCCTTCTCAGACTTGC & CACAGTGTTGAAGATGGTAAGG & 614 \\
Y2 receptor & AAATGGGTCCTGTCTGTGCC & TGCCTTCGCTGATGGTAGGG & 442 \\
Y4 receptor & AACCTACTCAATGCCAACCTGG & ATGTAGCAGACCAGGATGAAGG & 475 \\
Y5 receptor & CATTCGTAAGTCTTCTTGGC & ATCCAACAAGACAGAGGTCAGG & 169 \\
GAPDH & ATCACCATCTTCCAGGAGCG & TTCTGAGTGGCAGTGAGGGC & 300
\end{tabular}

GAPDH, glyceraldehyde-3-phosphate dehydrogenase. 
Figure 1 (A) Contraction elicited by $10^{-5} \mathrm{M}$ peptide $Y Y(P Y Y)$ compared with $10^{-6} \mathrm{M}$ acetylcholine chloride $(A C h)$ on the same colon nerve/muscle preparation. (B) Dose-response curve representing the effects of PYY on the proximal colon nerve/muscle preparation. Results are mean (SEM), $n$ $=7$.
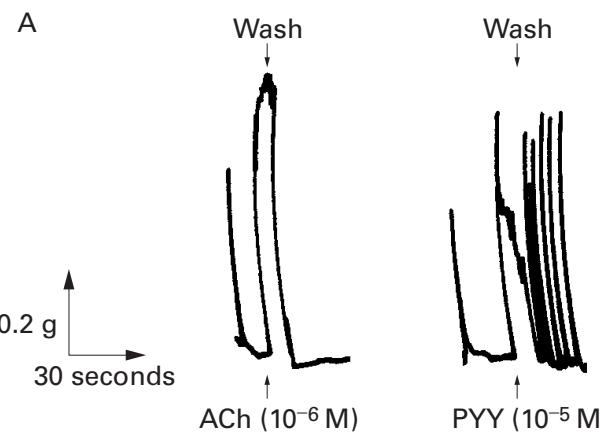

$\operatorname{PYY}\left(10^{-5} \mathrm{M}\right)$

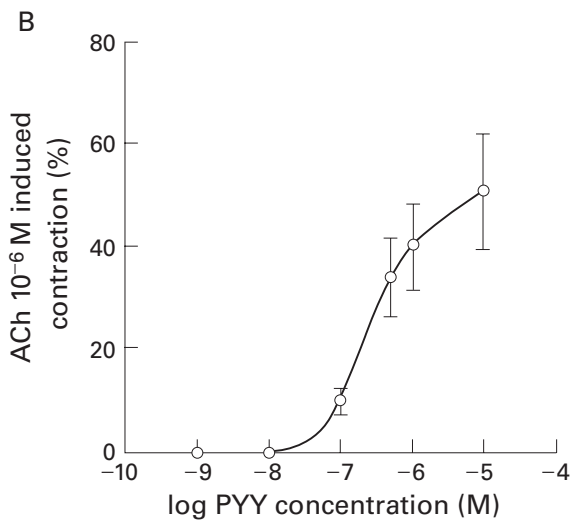

under an inverted microscope, coupled to a camera. The camera was linked to a computer, and cell length was measured using Image 1.59 software (NIH, Bethesda, Maryland, USA).

MEASUREMENT OF INTRACELLULAR $\mathrm{Ca}^{2+}$ CONCENTRATION $\left(\left[\mathrm{Ca}^{2+}\right]_{\mathrm{I}}\right)$

Changes in $\left[\mathrm{Ca}^{2+}\right]_{\mathrm{i}}$ were estimated by fluorescence measurement using the $\mathrm{Ca}^{2+}$ sensitive dye Indo 1 (Molecular Probes, Leiden, The Netherlands) as described elsewhere. ${ }^{23}$ Briefly, freshly dissociated colonic smooth muscle cells stored on glass coverslips were incubated with PSS/Hepes containing $1 \mu \mathrm{M}$ Indo 1 pentaacetoxymethylester (Indo $1 \mathrm{AM}$ ) for 25 minutes at room temperature. The cells were then washed with Indo $1 \mathrm{AM}$-free PSS/Hepes for 25 minutes. Coverslips were mounted in a perfusion chamber allowing continuous perfusion with fresh buffer, under an inverted microscope fitted with epifluorescence. The cell studied was illuminated at $360 \mathrm{~nm}$, and the light emitted was measured at $405 \mathrm{~nm}$ and 480 $\mathrm{nm}$. The fluorescence ratio $\mathrm{F}_{405}: \mathrm{F}_{480}$ allowed the estimation of $\left[\mathrm{Ca}^{2+}\right]_{\mathrm{i}}$.

Table 3 Effect of several antagonists on peptide YY (PYY) induced contraction of nerve/muscle preparations

\begin{tabular}{lll}
\hline & $\begin{array}{l}\text { PYY induced contraction after } \\
\text { pretreatment with the antagonist } \\
\text { Antagonist }\end{array}$ & p Value versus no pretreatment \\
\hline Tetrodotoxin $10^{-6} \mathrm{M}$ & $65.3(13.3)$ & 0.046 \\
Hexamethonium $3 \times 10^{-4} \mathrm{M}$ & $66.8(6.4)$ & 0.047 \\
Atropine $10^{-6} \mathrm{M}$ & $87.5(4.2)$ & 0.1511 \\
SR $1403333 \times 10^{-7} \mathrm{M}$ & $65.9(3.0)$ & 0.0156 \\
SR $489683 \times 10^{-6} \mathrm{M}$ & $100(0)$ & $\mathrm{NS}$ \\
BIBP $322610^{-5} \mathrm{M}$ & $100(0)$ & $\mathrm{NS}$ \\
Methiotepin $10^{-6} \mathrm{M}$ & $100(0)$ & $\mathrm{NS}$ \\
D-600 $10^{-5} \mathrm{M}$ & $0(0)$ & 0.001 \\
\hline
\end{tabular}

Results are expressed as a percentage of $10^{-6} \mathrm{M}$ PYY induced contraction and are mean (SD).
CHEMICALS

All chemical compounds were purchased from Sigma Chemicals (Saint Quentin Fallavier, France). Salts were purchased from Merck (Nogent sur Marne, France). BIBP 3226 was kindly provided by Boehringer Ingelheim Pharma KG (Biberach an den Riss, Germany). SR 140333 and SR 48968 were provided by Dr D Aubert (Sanofi Recherche, Toulouse, France). Collagenase was from Worthington (Lakewood, New Jersey, USA).

STATISTICAL ANALYSIS

The effects of antagonists were analysed by paired Student's $t$ test. Other statistical analyses were performed by analysis of variance.

\section{Results}

DOSE DEPENDENT CONTRACTION OF PROXIMAL COLON NERVE/MUSCLE PREPARATION INDUCED BY PYY

The proximal colon nerve/muscle preparation displayed spontaneous regular phasic activity over at least three hours. However, the frequency and amplitude of this basal activity differed from one preparation to another. PYY elicited a tonic dose dependent contraction of the preparation, starting at a concentration of $10^{-8} \mathrm{M}$. The contraction reached an amplitude of 50.7 (11.4)\% (mean (SEM); $\mathrm{n}=7$ ) of the $10^{-6} \mathrm{M} \mathrm{ACh}$ induced contraction in the presence of $10^{-5} \mathrm{M}$ PYY (fig 1A). The maximal amplitude was obtained after an incubation period with the peptide of about 10 seconds. The dose-response curve showed a typical sigmoid profile (fig 1B), with an $\mathrm{EC}_{50}$ (dose eliciting the half-maximal response) calculated at $3 \times 10^{-7} \mathrm{M}$.

PARTIAL MEDIATION OF PYY EFFECT ON PROXIMAL COLON THROUGH A NERVOUS PATHWAY

The application of $10^{-6} \mathrm{M}$ tetrodotoxin resulted in a large increase in frequency and amplitude of the spontaneous activity of the colon nerve/ muscle preparation, showing disinhibition of the strip basal activity. Tetrodotoxin inhibited about

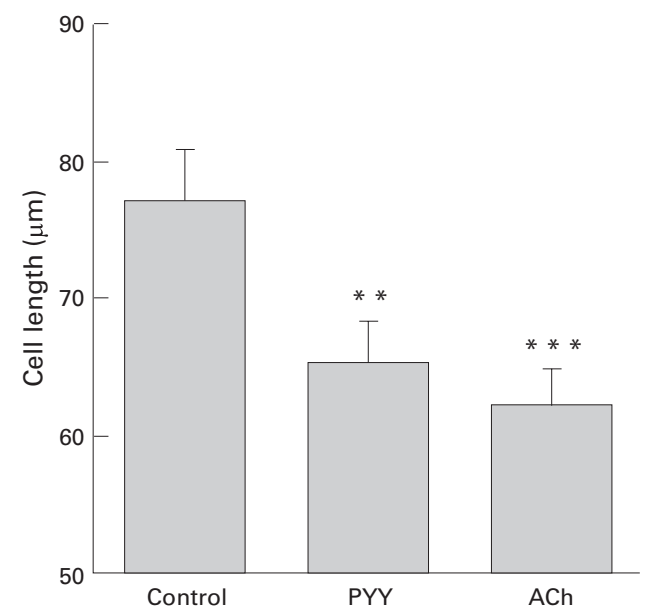

Figure 2 Effect of $10^{-6} \mathrm{M}$ acetylcholine chloride (ACh) and $10^{-6} \mathrm{M}$ peptide $Y Y(P Y Y)$ on the length of isolated colonic smooth muscle cells. This is a representative of the three experiments performed. Results are expressed as mean (SEM) $\left(n=60\right.$ cells). ${ }^{\star *} p<0.01,{ }^{\star *} p<0.001$ compared with control. 
Figure 3 Increase in intracellular $C \mathrm{a}^{2+}$ concentration in isolated smooth muscle cells after exposure to $10^{-5} \mathrm{M}$ peptide exposure to $10^{-5} \mathrm{M}$ peptide
YY (PYY) or $10^{-5} \mathrm{M}$ acetylcholine chloride (ACh), as observed using Indo-1 fluorescent $\mathrm{Ca}^{2+}$ dye.

Figure 4 Effect of neuropeptide $Y$ (NPY) (13-36) and [Leu31,Pro34]NPY on the proximal colon nerve/muscle preparation $(N M P)$. Results are expressed as mean (SEM), $n=7$. ACh, acetylcholine chloride.
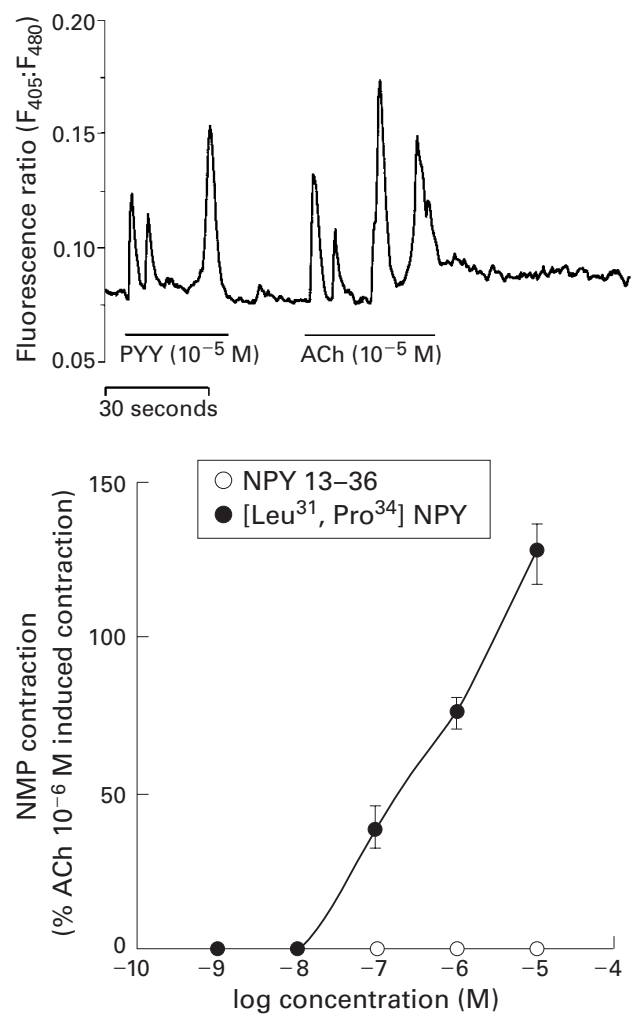

one third of the PYY induced contractions, suggesting involvement of the enteric nervous system in the PYY effect (table 3). Hexamethonium $3 \times 10^{-4} \mathrm{M}$ was also a moderate inhibitor of the PYY induced contraction, but had no effect on muscle basal activity. SR $1403333 \times 10^{-7} \mathrm{M}$, an NK1 receptor antagonist, also significantly reduced the PYY induced contraction. Atropine $10^{-6} \mathrm{M}$ induced slight, but not significant, inhibition of the PYY effect. Finally, methiotepin and the NK2 receptor antagonist SR 48968 had no effect on the nerve/muscle preparation basal activity and on the tonic contraction evoked by PYY.

\section{EFFECT OF PYY ON COLONIC SMOOTH MUSCLE} CELL LENGTH

The application of $10^{-6} \mathrm{M}$ PYY to freshly isolated colonic smooth muscle cells induced a reduction in cell length as compared with control cells exposed to buffer (65.5 (2.9) $\mu \mathrm{m}(\mathrm{n}=$ 60) $v 77.2$ (3.7) $\mu \mathrm{m}(\mathrm{n}=60)$ respectively, $\mathrm{p}<0.01$; fig 2). ACh $10^{-6} \mathrm{M}$ also significantly reduced smooth muscle cell length (64.2 (3.5) $\mu \mathrm{m} \quad(\mathrm{n}=60)$ compared with control cells, $\mathrm{p}<0.001)$. This reduction in cell length reflected contraction of the smooth muscle cells when exposed to PYY.

PYY INCREASED $\left[\mathrm{Ca}^{2+}\right]$, THROUGH THE ACTIVATION OF L-TYPE $\mathrm{Ca}^{2+}$ CHANNELS

The application of $10^{-5} \mathrm{M}$ D-600 completely abolished the spontaneous activities of the proximal colon nerve/muscle preparation. After D-600 pretreatment, PYY $10^{-6} \mathrm{M}$ was not able to elicit a contraction (table 3). Moreover, the exposure of freshly isolated smooth muscle cells to $10^{-5} \mathrm{M}$ PYY induced a rapid increase in $\left[\mathrm{Ca}^{2+}\right]_{\mathrm{i}}$ (fig 3). ACh $10^{-5} \mathrm{M}$ also increased $\left[\mathrm{Ca}^{2+}\right]_{i}$.

MEDIATION OF THE PYY EFFECT THROUGH THE Y4 RECEPTOR AND A POTENTIAL NEW Y RECEPTOR The Y1/Y4/Y5 agonist [Leu31,Pro34]NPY elicited a dose dependent contraction of the proximal colon nerve/muscle preparation (fig 4). This response was larger than that observed with PYY, but the dose-response curve did not show any plateau. At the highest dose $\left(10^{-5} \mathrm{M}\right)$, the contraction evoked by [Leu31,Pro34]NPY reached 114.0 (14.4)\% of the $10^{-6} \mathrm{M}$ ACh induced contraction $(\mathrm{n}=7)$. This effect was partly blocked by tetrodotoxin (data not shown). In contrast, the Y2 agonist NPY(13-36), which is also a partial Y5 agonist, was unable to elicit any motor effect on the proximal colon nerve/muscle preparation (fig 4), even when tested at high concentration $\left(10^{-5} \mathrm{M}\right)$. Thus it is unlikely that the PYY effect occurs through a Y 2 or Y 5 receptor.

The dose-response curve elicited by PP was leftward shifted as compared with that of PYY (fig 5A). However, it was strongly blocked by tetrodotoxin application. Thus, a Y4 receptor seemed to be localised on the enteric nerves.

NPY induced a dose dependent contraction with the same potency as PYY (fig 5B), and tetrodotoxin application blocked its effects at around the same level as the PYY induced contraction.

BIBP 3226, a selective Y1 receptor antagonist, did not affect the PYY induced contraction at any of the doses tested $\left(10^{-7}-10^{-5} \mathrm{M}\right.$; data not shown). The ability to antagonise the $\mathrm{Y} 1$ receptor was tested on rabbit saphenous vein (data not shown) as described by Jacques and
Figure 5 (A) Comparison of contractions in the proximal colon nerve/muscle preparation (NMP) induced by peptide $Y Y(P Y Y)$ and pancreatic peptide (PP) before and after tetrodotoxin $10^{-6} \mathrm{M}$ application. (B)

Comparison of contractions in the proximal colon nerve/muscle preparation induced by PYY and neuropeptide Y (NPY) before and after tetrodotoxin $10^{-6} \mathrm{M}$ application. ACh, acetylcholine chloride. TTX, tetrodotoxin. ${ }^{*} p<0.05,{ }^{*} p<0.01$ compared with before tetrodotoxin application.
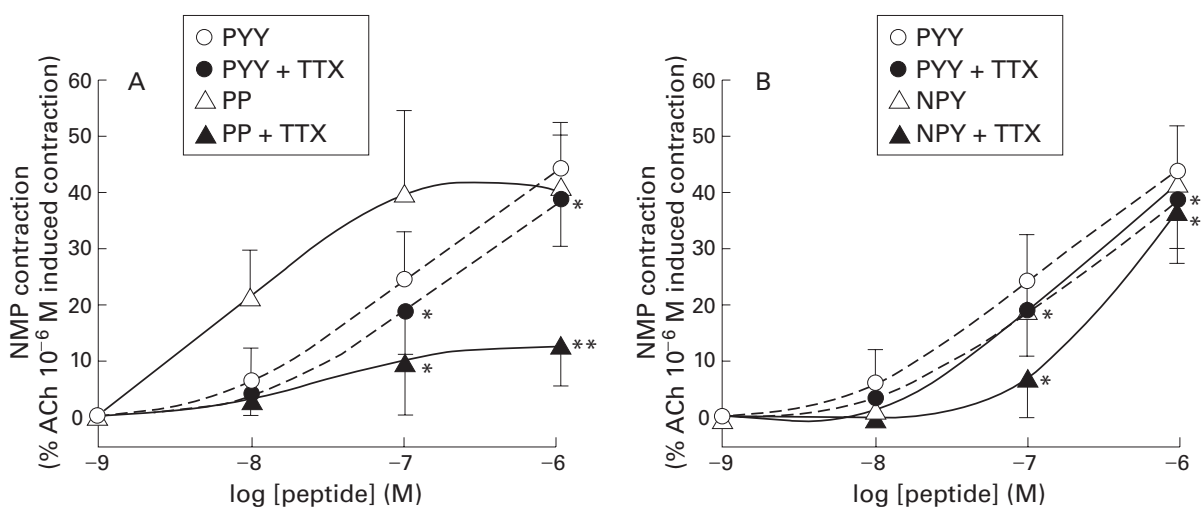


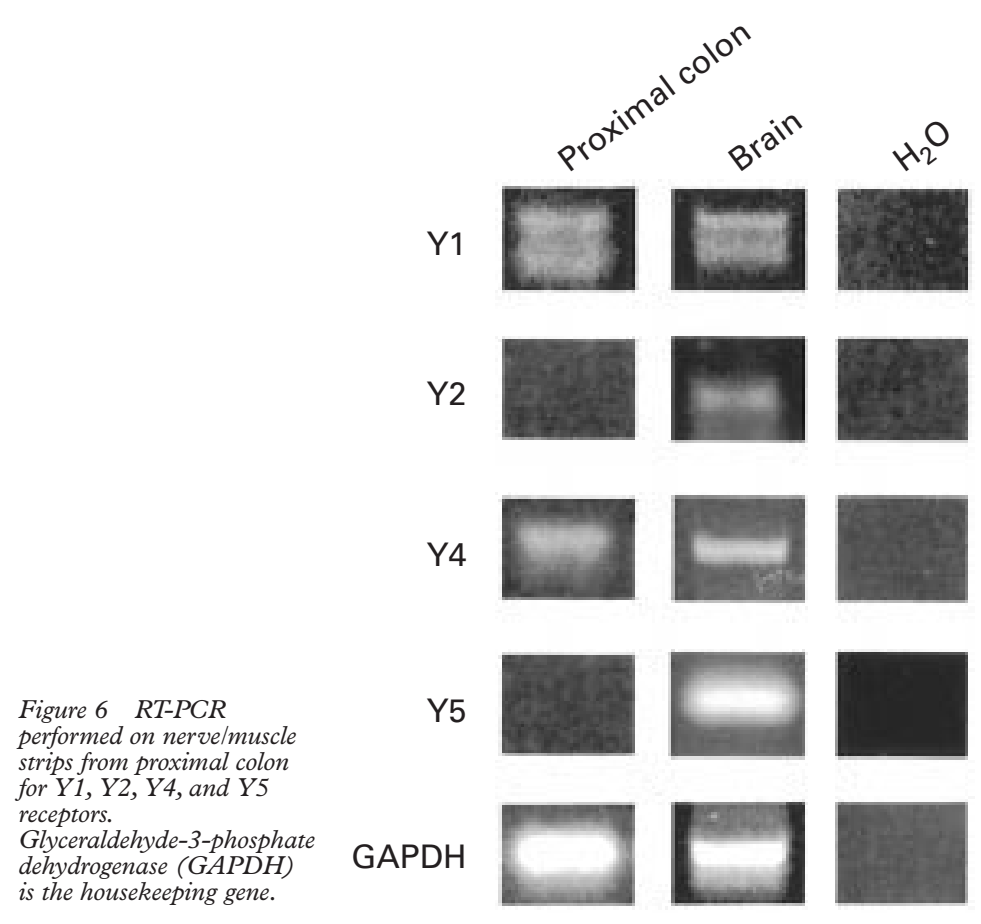

coworkers. ${ }^{24}$ Thus, this receptor did not seem to play a significant role in the contractile effect of PYY.

Finally, RT-PCR was performed on the proximal colon nerve/muscle preparation using specific primers for $\mathrm{Y} 1, \mathrm{Y} 2$, Y 4 , and $\mathrm{Y} 5$ receptors. The presence of $\mathrm{mRNA}$ coding for $\mathrm{Y} 1$ and Y4 receptors, but not for Y2 and Y5 receptors, was established (fig 6).

\section{Discussion}

PYY is a well known modulator of gastrointestinal function, including motility, but little is known about its colonic motor effects. Our study aimed to characterise the effects of PYY on rat colon, using nerve/muscle preparations. This model allowed us to bypass the potential systemic effects of circulating hormones and brain regulation associated with an in vivo study. Our results show that PYY induces dose dependent contraction of rat proximal colon in vitro.

Nerve blocking by tetrodotoxin resulted in an increase in the frequency and amplitude of spontaneous contractions. Such an effect has been described for cat colon. ${ }^{25}$ Moreover, in a recent study investigating the neuronal immunoreactivity for different neurotransmitters in the plexus of the colon, a predominance of inhibitory pathways, especially neurones expressing mRNA for NO synthase, was found in the proximal colon. ${ }^{26}$ Thus nerve blocking by tetrodotoxin may inactivate this basal inhibition of proximal colon activity, explaining this observation. Tetrodotoxin inhibited one third of the PYY induced contractions of the rat colon nerve/muscle preparation, indicating partial involvement of the enteric nervous system. Hexamethonium produced a similar inhibition. Acetylcholine is known to play an important role in neurone-neurone transmission through nicotinic receptors; thus the breakdown of this cholinergic outflow may inhibit the release of several neurotransmitters acting on colonic motility. In our study, acetylcholine release in the neuromuscular junction after PYY application seemed weak, as atropine inhibited about $10 \%$ of the colonic response and this inhibition was not significant. The NK1 and NK2 receptors are both known to be present in rat proximal colon and play a role in colonic motility. ${ }^{27}$ The NK1 receptor antagonist SR 140333 moderately inhibited the PYY effect, whereas the NK2 receptor antagonist SR 48968 was devoid of effect. Substance P, the strongest endogenous agonist for the NK1 receptor, may be a mediator of the PYY effect. With respect to the 5HT receptors, the $5 \mathrm{HT}_{1}$ and $5 \mathrm{HT}_{2}$ subtypes have been shown to be the most effective in mediating 5HT induced rat proximal colon contraction. ${ }^{28}$ In our study, the $5 \mathrm{HT}_{1 / 2}$ antagonist methiotepin was ineffective, showing lack of involvement of 5HT in the PYY effect. Thus the nervous part of the action of PYY on colonic motor activity seems to be complex. Nevertheless, it involves nicotinic interneurones and neurokininergic motoneurones.

Some of the action of PYY on colon smooth muscle is exerted on the smooth muscle cells, as its application resulted in a decrease in cell length, indicating myocyte contraction. To our knowledge, this is the first study to show clearly a direct contractile effect of PYY on smooth muscle cells freshly isolated from a gastrointestinal tissue.

Blocking L-type $\mathrm{Ca}^{2+}$ channels with D-600 completely abolished the PYY effect, showing the involvement of such channels in the contraction elicited by PYY. Moreover, when applied to isolated smooth muscle cells, PYY induced an increase in $\left[\mathrm{Ca}^{2+}\right]_{\mathrm{i}}$. Thus the PYY mediated contraction is $\mathrm{Ca}^{2+}$ dependent and requires L-type $\mathrm{Ca}^{2+}$ channels. Another study showed mobilisation of intracellular $\mathrm{Ca}^{2+}$ by PP fold peptides on vascular smooth muscle cells. ${ }^{29}$ This must be related to the $\mathrm{G}_{\mathrm{i}} / \mathrm{G}_{\mathrm{o}}$ protein coupling of $\mathrm{Y}$ receptors; indeed, such coupling allows $\mathrm{Ca}^{2+}$ entry into the cell through membrane $\mathrm{Ca}^{2+}$ channels, as observed in vascular myocytes. ${ }^{30}$

We next investigated the receptors involved in the PYY mediated contraction using pharmacological tools. PP applied to proximal colon muscle showed a leftward shift of the dose-response curve, compared with that of PYY and NPY, which was mainly blocked by tetrodotoxin. According to Lundell and co-workers, ${ }^{31}$ PP has a 10000 -fold higher affinity for the Y4 receptor than PYY and NPY, which explains this shift. These results, reinforced by the presence of mRNA encoding the Y4 receptor, suggest the involvement of a nervous Y4 receptor, but the effect of PYY on rat colon implies that this is unlikely to be the only receptor. As NPY induced a contraction with the same potency as PYY, and tetrodotoxin application blocked the muscle response to NPY and PYY to a similar extent, we suggest that the other receptor involved is located on the smooth muscle cell and has the same affinity for these two peptides. As shown in table 1, $\mathrm{Y} 1, \mathrm{Y} 2$, and $\mathrm{Y} 5$ receptors display such properties. The Y2 receptor agonist, and to a lesser 
extent the Y5 agonist NPY(13-36), were devoid of effect, and no Y2 and Y5 receptor mRNA was found. These results therefore indicate that $\mathrm{Y} 2$ and $\mathrm{Y} 5$ receptors are not involved in the PYY mediated effect on rat proximal colon. Moreover, we found that the $\mathrm{Y} 1 / \mathrm{Y} 4 / \mathrm{Y} 5$ agonist [Leu31,Pro34]NPY induced a stronger contraction of rat proximal colon in vitro than PYY. This contraction was partly blocked by tetrodotoxin (data not shown). Moreover, Y1 receptor mRNA was found to be present by RT-PCR. Taken together, these results indicate that the receptor is closely related to the Y1 receptor, as it displays good affinity for NPY, PYY, and [Leu31,Pro34]NPY. However, the Y1 receptor antagonist BIBP 3226, which antagonised the PYY effect on rabbit saphenous vein (data not shown), was not able to block the PYY effect on rat proximal colon. We can hypothesise that PYY acts through a "Y1-like" receptor subtype, which displays a high affinity for PYY, NPY, and [Leu31,Pro34]NPY, but which is not antagonised by BIBP 3226. The recently discovered Y6 receptor seems to correspond to this pharmacological profile, ${ }^{15}$ but a recent study documents its absence from rats. ${ }^{17}$ Moreover, it has been found in a truncated non-functional form in the gastrointestinal tract in humans. Our hypothesis is reinforced by a recent study that failed to detect any Y1 receptor on Wistar rat colonic smooth muscle cells using immunohistochemistry. ${ }^{32}$ Another recent study on the receptors involved in NPY induced contraction corroborates in part the present work. ${ }^{33}$ Indeed, the authors found a nervous Y4 receptor and a lack of effect of BIBP 3226. However, in contrast with our study, NPY(13-36) also induced a contraction, which was unaffected by tetrodotoxin but strongly inhibited by atropine, associated with the presence of mRNA encoding the Y2 receptor. It is noteworthy that this study was performed in Sprague-Dawley rats, whereas we used Wistar rats. This difference in strain may explain why the results are closely related but not identical.

In conclusion, we show that PYY, a peptide released by enteroendocrine L cells, stimulates proximal colon motility in vitro in rats. We can suggest two pathways for this effect: firstly, a nervous pathway involving a Y4 receptor which stimulates nicotinic transmission in enteric plexuses; these interneurones then stimulate motorneurones; secondly, a direct effect exerted by PYY on colonic smooth muscle cells, which results in the opening of L-type $\mathrm{Ca}^{2+}$ channels. The receptor involved is a Y1-like receptor which is not the $\mathrm{Y} 6$ receptor described in mice and humans, and therefore may be a new member of the $\mathrm{Y}$ receptor family.

Some of the results of this study appeared in Gut 1997;41 (suppl 3):A42.

1 Tatemoto K. Isolation and characterization of peptide YY (PYY), a candidate gut hormone that inhibits pancreatic exocrine secretion. Proc Natl Acad Sci USA 1982;79:2514-18.

2 Adrian TE, Ferri GL, Bacarese-Hamilton AJ, et al. Human distribution of a putative new gut hormone, peptide YY. distribution of a putative new gut
Gastroenterology $1985 ; 89: 1070-7$.

3 Iesaki K, Sakai T, Satoh M, et al. Distribution of enteric peptide YY in the dog gastrointestinal tract. Peptides 1995 16:1395-402.
4 Sheikh SP. Neuropeptide Y and peptide YY: major modulators of gastrointestinal blood flow and function. $\mathrm{Am} F$ tors of gastrointestinal blood

5 Fu-Cheng X, Anini Y, Chariot J, et al. Mechanisms of peptide YY release induced by an intraduodenal meal in rats: neural regulation by proximal gut. Pflügers Arch 1997;433:571-9.

6 Zhang T, Brubaker PL, Thompson JC, et al. Characterization of peptide-YY release in response to intracolonic infusion of amino acids. Endocrinology 1993;132:553-7.

7 Longo WE, Ballantyne GH, Savoca PE, et al. Short-chain fatty acid release of peptide YY in the isolated rabbit distal colon. Scand 7 Gastroenterol 1991;26:442-8.

8 Plaisancié P, Dumoulin V, Chayvialle JA, et al. Luminal peptide YY-releasing factors in the isolated vascularly perfused rat colon. 7 Endocrinol 1996;151:421-9.

9 Cherbut C, Ferrier L, Rozé C, et al. Short chain fatty acids modify colonic motility through nerves and polypeptide YY release in the rat. Am f Physiol 1998;275:G1415-22

10 Chen CH, Rogers RC, Stephens RL, Jr. Intracisternal injection of peptide YY inhibits gastric emptying in rats. Regul Pep. 1996;61:95-8.

11 Wager-Pagé SA, Ghazali B, Anderson W, et al. Neuropeptide Y, peptide YY, and pancreatic polypeptide modulate duodenal and colonic motility at a thoracic spinal site in rats. Peptides 1992;13:807-13.

12 Fox-Threlkeld JAET, Daniel EE, Christinck F, et al. Peptide YY stimulates circular muscle contractions of the isolated perfused canine ileum by inhibiting nitric oxide release and enhancing acetylcholine release. Peptides 1993;14:1171-8.

13 Hellström PM. Mechanisms involved in colonic vasoconstriction and inhibition of motility induced by neuropeptide Y. Acta Physiol Scand 1987;129:549-56.

14 Sawa T, Mameya S, Yoshimura M, et al. Differential mechanism of peptide YY and neuropeptide $\mathrm{Y}$ in inhibiting motility of guinea-pig colon. Eur F Pharmacol 1995;276: 223-30

15 Gehlert DR. Multiple receptors for the pancreatic polypeptide (PP-fold) family: physiological implications. Proc Soc Exp Biol Med 1998;218:7-22.

16 Blomqvist AG, Herzog H. Y-receptor subtypes-how many more? Trends Neurosci 1997;20:294-8.

17 Burkhoff A, Linemeyer DL, Salon JA. Distribution of a novel hypothalamic neuropeptide Y receptor gene and its absence in rat. Brain Res Mol Brain Res 1998;53:311-16.

18 Laburthe M, Chenut, B, Rouyer-Fessard C, et al. Interaction of peptide YY with rat intestinal epithelial plasma membranes: binding of the radioiodinated peptide. Endocrinology 1986;118:1910-17.

19 Aubé AC, Blottière HM, Scarpignato C, et al. Inhibition of acetylcholine induced intestinal motility by interleukin $1 \beta$ in the rat. Gut 1996;39:470-4.

20 Chomczynski P, Sacchi N. Single-step method for RNA isolation by acid guanidium thiocyanate-phenol-chloroform extraction. Anal Biochem 1987;162:156-9.

21 Goumain $M$, Voisin T, Lorinet AM, et al. Identification and distribution of mRNA encoding the Y1, Y2, Y4 and Y5 receptors for peptides of the PP-fold family in the rat intestine and colon. Biochem Biophys Res Commu. 1998; 247:52-6.

22 Blottière HM, Loirand G, Pacaud P. Rise in cytosolic $\mathrm{Ca}^{2+}$ concentration induced by $\mathrm{P}_{2}$-purinoceptor activation in isolated myocytes from the rat gastrointestinal tract. $\mathrm{Br} \mathcal{F}$ Pharmacol 1996;117:775-80.

23 Pacaud P, Bolton TB. Relation between muscarinic receptor cationic current and internal calcium concentration in guinea-pig jejunal smooth muscle cells. $\mathcal{f}$ Physiol (Lond) 1991;441:477-99.

24 Jacques D, Cadieux A, Dumont Y, et al. Apparent affinity and potency of BIBP3226, a non-peptide neuropeptide Y and potency of BIBP3226, a non-peptide neuropeptide Y receptor antagonist, on purported neuropeptide Y

25 Christensen J, Anuras S, Arthur C. Influence of intrinsic nerves on electromyogram of rat colon in vitro. $A m \mathcal{F}$ Physiol 1978;234:E641-7.

26 Takahashi T, Nakamura K, Nakao K, et al. Regional differences of nitric oxide synthase expression in the myenteric plexus in proximal and distal colon in rats [abstract]. Gastroenterology 1997;112:A835.

27 Maggi CA, Catalioto RM, Crissuoli M, et al. Tachykinin receptors and intestinal motility. Can f Physiol Pharmacol 1997;75:696-703.

28 Gelal A, Guven H. Characterisation of 5-HT receptors in rat proximal colon. Gen Pharmacol 1998;30:343-6.

29 Shigeri Y, Nakajima S, Fujimoto M. Neuropeptide YY1 receptor-mediated increase in intracellular $\mathrm{Ca}^{2+}$ concentration via phospholipase C-dependent pathway in procine aortic smooth muscle cells. F Biochem 1995;118:515-20.

30 Lepetre N, Mironneau J, Morel JL. Both alpha 1A- and alpha 2A-adrenoceptor subtypes stimulate voltageoperated L-type calcium channels in rat portal vein myocytes. Evidence for two distinct transduction pathways. 7 Biol Chem 1994;269:29546-52.

31 Lundell I, Statnick MA, Johnson D, et al. The cloned rat pancreatic polypeptide receptor exhibits profound differences to the orthologous human receptor. Proc Natl Acad Sci USA 1996;93:5111-15.

32 Jackerott M, Larsson LI. Immunocytochemical localization of the NPY/PYY Y1 receptor in enteric neurons, endothelial cells, and endocrine-like cells of the rat intestinal tract. f Histochem Cytochem 1997;45:1643-50.

33 Félétou M, Rodriguez M, Beauverger P, et al. NPY receptor subtypes involved in the contraction of the proximal colon of the rat. Regul Pept 1998;75:221-9. 